\title{
Editorial
}

\section{Post-COVID: Together, we will do better}

\author{
Minh T. Do, PhD, Associate Scientific Editor, HPCDP Journal \\ Barry Pless, MD, FRCPC, OC, Associate Scientific Editor, HPCDP Journal
}

Published online November 18, 2020

Tweet this article

The COVID-19 pandemic has affected everyone, and none more than the families and friends of those who have passed away. Many of its effects will be felt long after the pandemic is over, prompting the question, how can we do better next time? The Canadian Pandemic Influenza Plan for the Health Sector ${ }^{1}$ is a comprehensive document containing over 500 pages of detailed guidelines, tools and planning checklists. This document was updated in 2018 based on lessons learned from the 2009 H1N1 pandemic. ${ }^{2}$ A similar report will undoubtedly follow when COVID-19 has ended, to serve as a guide to how we can better prepare for the next pandemic, whether it be a return of COVID-19 or something else.

Because a pandemic is by definition a global health threat, our view is that a concerted global response is required. To this point, however, the response to date has differed from country to country. Sweden's decision to keep the country open $^{3}$ is in stark contrast to countries that closed their borders early. ${ }^{4}$ More troubling was the emergence of competing national responses to mitigation. We saw unprecedented competition among countries, amounting at times to frenzy, to acquire personal protective equipment and medical supplies. Some governments are even now offering huge sums in a race to secure an "inside track" on access to candidate vaccines. Declaring COVID-19 a pandemic was intended to highlight the need for greater unity and global collaboration to study and contain the virus. We need more global collaboration, not less.

Thirty-five years ago, Geoffrey Rose published a landmark paper. ${ }^{5}$ "Sick Individuals and Sick Populations" challenged traditional public health views. Rose argued that only small benefits were gained by treating high-risk individuals, whereas large potential gains would follow "treating" populations. Rose called this approach "radical" but in the context of COVID-19 his reasoning does not seem at all radical. From his perspective, focussing only on those first thought to be at high risk would have been flawed, yet in some respects this is what happened in parts of Canada. This initial approach has gradually given way to a population approach for disease prevention, which we believe should remain at the heart of strategies intended to prevent or better manage future pandemics. We urge, however, that the world take a further step: expanding Rose's view of sick populations to include a "sick world." This expanded view would entail extending current surveillance systems and countermeasure strategies to include animal, environmental and human health. To do this, it is important to work effectively across disciplines, which requires shifting our practices to adopt the "One World, One Health" paradigm. ${ }^{6}$

We would also need to make greater use of modern predictive analytics and to extract key information from a variety of data sources beyond the health realm. Advanced tagging algorithms allow for signal detection across digital operations that can provide clues in identifying emerging health threats. This is not much different from the approach currently used to obtain global epidemiological updates using data collated from other publicly available websites. ${ }^{7}$ For the opioid crisis in Canada, for example, the Public Health Agency of Canada (PHAC) explored non-traditional data sources to gain insight into the increase in overdoses and deaths. One source was social media data, ${ }^{8}$ wherein changes in sentiments towards the use of opioids and their perceived dangers were identified. In a second paper, PHAC used paramedic data to detect spikes in opioid overdose cases before patients made contact with the health care system. ${ }^{9}$ In another example, Health Canada used syndromic surveillance to identify the first vapingassociated lung illness in Canada in the Consumer and Hazardous Products Safety Directorate database. ${ }^{10,11}$ While this database was initially designed to support regulatory functions, it was re-tooled to permit surveillance of vaping injuries. ${ }^{11}$ If we succeed in adapting Rose's view to the idea of a "sick world," advanced analytics could provide much of the knowledge needed to prevent or control future outbreaks.

As with any challenge, the current pandemic has presented many opportunities for improvement. Whether we extend Rose's views to the global level or to the use of new analytical methods to better detect signals of emerging health threats, we will still need far more fresh thinking. We will need to foster more dialogue and strengthen links across disciplines to fully achieve an effective interdisciplinary and multidisciplinary approach to managing pandemics. Early in the COVID-19 pandemic, world leaders responded quickly with fiscal interventions on a massive scale. It is time for the many disciplines within the scientific community to open their toolboxes, but to use the tools properly, continued support will be essential. The next pandemic could be worse. We must then act quickly and together; we will need to synthesize the information then available into actionable intelligence. 
Above all, we will need to work-not as individuals, but as a team-thinking "radically" and with a clear sense of direction.

\section{Conflicts of interest and statement}

None.

The content and views expressed in this article are those of the authors and do not necessarily reflect those of the Government of Canada.

\section{References}

1. Public Health Agency of Canada. The Canadian pandemic influenza plan for the health sector. Ottawa (ON): Her Majesty the Queen in Right of Canada; 2006 [Catalogue No.: HP4010/2006E-PDF]. 550 p.

2. Pan-Canadian Public Health Network. Canadian pandemic influenza preparedness: planning guidance for the health sector. Ottawa (ON): Her Majesty the Queen in Right of Canada; 2018 [Catalogue No.: HP40-144/2018EPDF]. 64 p. Available from: https:// www.canada.ca/en/public-health /services/flu-influenza/canadian -pandemic-influenza-preparedness -planning-guidance-health-sector.html

3. Habib H. Has Sweden's controversial covid-19 strategy been successful? BMJ. 2020;369:m2376. https://doi.org /10.1136/bmj.m2376. Erratum in: BMJ. 2020;369:m2407. https://doi.org/10 $.1136 /$ bmj.m2407

4. Jones A. How did New Zealand become Covid-19 free? [Internet]. London (UK): BBC News; 2020 Jul 9 [cited 2020 Aug 18]. Available from: https://www.bbc.com/news/world -asia-53274085

5. Rose G. Sick individuals and sick populations. Int J Epidemiol 1985; 14(1):32-8. https://doi.org/10.1093/ije $/ 14.1 .32$

6. Fisman DN, Laupland KB. The 'One Health' paradigm: time for infectious diseases clinicians to take note? Can J Infect Dis Med Microbiol. 2010;21(3): 111-4. https://doi.org/10.1155/2010 /420628
7. Dong E, Du H, Gardner L. An interactive web-based dashboard to track COVID-19 in real time. Lancet Infect Dis. 2020;20(5):533-4. https://doi.org /10.1016/S1473-3099(20)30120-1. Erratum in: Lancet Infect Dis. 2020; 20(9):e215. https://doi.org/10.1016 /S1473-3099(20)30509-0

8. Tibebu S, Chang V, Drouin C, Thompson W, Do MT. At-a-glance - What can social media tell us about the opioid crisis in Canada? Health Promot Chronic Dis Prev Can. 2018;38(6): 263-7. https://doi.org/10.24095/hpcdp .38.6.08

9. Do MT, Furlong G, Rietschlin M, et al. At-a-glance - What can paramedic data tell us about the opioid crisis in Canada? Health Promot Chronic Dis Prev Can. 2018;38(9):339-42. https:// doi.org/10.24095/hpcdp.38.9.06

10. Landman S, Dhaliwal I, Mackenzie CA, Martinu T, Steele A, Bosma KJ. Life-threatening bronchiolitis related to electronic cigarette use in a Canadian youth. CMAJ. 2019;191(48): E1321-E1331. https://doi.org/10.1503 /cmaj.191402

11. Do MT, McFaull S, Guttman L, Ghandour L, Hardy J. Strengthening surveillance of consumer products in Canada: the vaping example. Health Promot Chronic Dis Prev Can. 2020; 40(10):309-13. https://doi.org/10.24095 /hpcdp.40.10.02 